\title{
IOWA'S STRUGGLE FOR A TERRITORIAL GOVERNMENT
}

\section{By Kenneth E. Colton}

The "Iowa District," the settled area west of the Mississippi River, passed from the administrative control of the Territory of Michigan to that of the Territory of Wiseonsin on the Fourth of July, 1836. At almost the same moment a movement was born seeking to separate this distriet from Wisconsin Territory and to establish in it a territorial government of its own . . . in a region which had been opened to white settlement only since June, 1833, and which had received its first eivil government in $\mathbf{1 8 3 4}$. Previous to the Iowa District no other territory under the jurisdiction of the federal government had witnessed such a speedy transition frem lands held by the roving Indian to lands filled with thriving white settlements, nor had any territory clamored so soon for a separate government.

That there would be a division of Wisconsin Territory was obvious from a mere inspection of the vast region organized by Congress in 1836; it was apparent then that Wisconsin Territory was not carved in its permanent form, but that it would be divided into other territorial governments as occasion arose. The question, therefore, was WHEN, when did an occasion arise that a new territory was needed?

The arguments offered to support the demand for a separate territorial government west of the Mississippi were several. The tides of immigration were sweeping into the Iowa District even faster than into the older regions of Wisconsin, and were giving to that western area the requisite population to warrant a separate government; the increase in population also emphasized the claim that Wisconsin Territory was too large an expanse to be adequately governed from one semiisolated center; furthermore, it was pointed out that the provisions of the Northwest Ordinance provided that eventually a state must be formed out of the Wisconsin Territory whose western boundary was fixed as the Mississippi River, there- 
fore, western men asked, why postpone the inevitable? Other reasons supplemented these obvious ones. It was urged that since the governor was also superintendent of Indian affairs, the seat of government should be nearer to the recently dispossessed Indians whom the encroaching settlers had shoved westward by the treaties at Prairie du Chien in the 1820's, by those at Rock Island with the Winnebagos and the Sauks and Foxes in 1832, and by the later treaties of 1836 and 1837 which pushed the western Indian boundary line still farther towards the Missouri River. Another reason, little seen in print, but which undoubtedly existed, was that as two territories they would receive a combined total of grants-in-aid from the federal treasury greater than if the two governments were but one-mail routes, road development projects, river and harbor improvements, light houses, and land pre-emption bills all demanded congressional approval and federal funds before the respective regions could receive these benefits. And, be it noted, territories in the nineteenth century had a justified reputation for wheedling from the federal treasury all the funds they possibly could. Another argument for dividing the large. Wisconsin Territory was a refinement of the one above, and, though an induced one, seems nevertheless valid; while the interests of the two sections of. Wisconsin were similar in the many, points common to all frontier settlements, there were nevertheless enough differences between what each division thought was best for its respective district to make it desirable for both sections to divide. The eastern region of Wisconsin was almost exclusively interested in improving the waterway connections with the east via the Great Lakes, while the western sections, and this included the Iowa District, although likewise interested in canals, roads, and railroads connecting the Mississippi with the Lakes-a favorite speculation-were even more interested in improving the transportation facilities of the Mississippi so as to profit by the markets on the lower reaches of that river and by the profitable trade that eame by the Ohio. With the exception of Dubuque, whose lead mines gave it an identity of interest with those of the miners at Galena and Mineral Point, Iowa's early interests were already agricultural and to some extent 
commercial. Up to 1836 settlements in Wisconsin had been stimulated largely by speculative interests, either in lead (the southwestern part) or in land (the lake region), whereas Iowa from the beginning drew principally the squatter farmer and the homesteader. There were, therefore, pronounerd differences in immediate objectives between the farming and commercial communities of the west and the speculative mining and commercial centers in "Wisconsin proper." It is conceivable that it occurred to the reflective minds of the truc Badgers that their own particular interests might be the better advanced if they were soon separated from this fast growing giant on the west . . o otherwise their grants-in-aid for territorial roads, canals, harbors, etc., would soon have to be shared with the increasing and competitive demands of that western region. This altruistic form of economy was not especially desired. A further cause for interest in a division of the large Wisconsin Territory was the hope offered to the politically ambitious of preferment and advancement both by appointive and by elective office. This last incentive for division became stronger, of course, as the certainty of the event grew.

The amazing fact about the movement for an Iowa Territory was its early inception and the immediate assumption by all parties that it would soon be formed. Made a part of the new Wisconsin Territory in July, the Iowa District was talking in terms of separation and a territorial government of its own by the late fall. months of the same ycar. An expectation of a speedy division of Wisconsin Territory is seen in the debates of the first session of the territorial legislature which met in the fall months of 1836 in the jerry-built town of Belmont, Wisconsin. This expectation is clearly seen in the maneuvers and in the heated discussions that centered around the controversial question of locating the capitol of the new territory. Twenty-two years after that bitter wrangling session, Tibenezer Childs wrote of those debates, "we (members of the Council in Wisconsin proper) contended that members representing the region west of the Mississippi, though they had a legal right, yet they had no just right to vote on and determine the permanent seat of government for Wisconsin Ter- 
ritory as they expected soon to be set off into a separate Territory of their own. ..." $"$ The legislators from the Iowa side of the river likewise held visions of a separate government in the near future, in fact much of the strife and loss of tempers occasioned by this debate was attributable to this expectation, as is suggested in the observation of Lyman C. Draper, an eminent Wisconsin historian: "It is quite evident that the Des Moines County Delegation in both houses favored the location [of the capitol] at some central and convenient point between the Mississippi and Lake Michigan, anticipating the early division of the Territory of Wisconsin, and the organization of the Territory of Iowa; when they apparently hoped to secure the location of the eapitol in their portion of Iowa Territory. . . ",

It was with such antieipatory hopes that Burlington, Bellevue, Dubuque, and Peru in the Iowa District entered the contest to gain the capitol of territorial Wisconsin for their town. ${ }^{3}$ Besides the glory and prestige it gave, the advantages of having the seat of government in a given community were tangible and material-per se it attracted additional settlers to that town, it boomed the sale of land lots (and raised their prices ... important), increased the business of professional men, particularly lawyers, and stimulated the general mercantile and business life of the community. Naturally enough the prize was eagerly sought by all the struggling towns--in Iowa as well as in Wisconsin. In addition to its immediate advantages, such a political triumph would give that Iowa town a decided edge in the later contest for the location of the capitol of an Iowa territory. The long forethought of the ambitious Iowa towns is, therefore, easily understood.

Early in the contest Dubuque was an avowed candidate, and made an aggressive and a confident campaign for the honor, but she lost after a prolonged acrimonious struggle to James Doty's speculation at Madison and to her less obstinate and more amenable neighbors at Burlington, who secured the temporary site of the eapitol until the permanent buildings

IWisconsin Historical Collections, IV, 188.
I Ibid. VI, 396.

'Joseph Schafer. The Wisconsin Lead Rcgion (State Historical Society of Wis. consin, Madison, 1932), p. 60 . 
could be completed at Madison City. This struggle for the location of Wisconsin's first capitol left strained and bitter feelings in the wake of its settlement. Dubuque had entertained such high hopes of securing the prize that she did not readily forget the loss, especially was she embittered by the momory that her defeat was in part attributable to the solid vote of the Des Moines County delegation against her ambitious elaims. 'Together: with other defeated towns, Dubuque sought several times that winter to upset the decision taken, but to no avail. For a long time thereafter reverbrations of this sectional jealousy, particularly on the part of Dubuque, could be heard rumbling in the controversies of the Iowa District; Peter Hill Engle of Dubuque was severely taken to task by his local newspaper, the Iowa News, for voting in the territorial legislature to give the legislative printing to James Clarke's better equipped Burlington Gazette; even in 1838 Dubuque still appeared to have nourished a vain hope that the capitol of the Territory of Iowa would be located there; and in the same year Engle himself introduced a notice of this coolness between the sections of the Iowa District into his congressional campaign in Iowa's first election as a territory.' Fortunately, this feeling never extended to the point where one community was willing to place obstacles in the way of establishing an Iowa territory rather than see the advantage go to another section-although there was a definite reluctance to see the last hope of that advantage finally disappear. It was indeed fortunate that co-operation prevailed, for it has been said that the organization of the Territory of Wisconsin was delayed for some time due to the sharp jealousies between the lead mining Galena districts and fur trading, land speculating Green Bay. ${ }^{5}$ The problems, interests, and aspirations in the Iowa District were sufficiently similar so that in the final balance all could join together in urging upon Congress the wisclom of dividing Wisconsin Territory.

In the last analysis, however, no matter how convincing the logic, how great the need, how powerful the ambition, or how

4ozva Ncaus, February 3, 1938; letter of Judge A. M. Smith to Charles Masən dated at Prairie du Chien, September 22, 1838, Mason Colloction in the Historical, Memorial and Art Dept. of Iowa.

${ }^{5}$ Louis Peizer, Henry Dodge (Iowa City, 1911), p. 129. 
strong the private motive, the creation of Iowa Territory depended not on the will of the people affected, nor upon the local legislature, as much as it depended upon the action of Congress. But the attention of Congress in 1836-1837 was almost exclusively centered in heated and continuous debates over the merits of national banks versus sub-treasuries and over the propriety of pre-emption grants to squatters, in addition Congress was harried by the first rumbling threats of the slavery controversy. The territorial wards of the federal government, therefore, had first to gain the attention of Congress to their demands, and then had to compete with these nation-gripping questions for time for their consideration.

The first effort to secure congressional action on a proposal to create an Iowa Territory may have been stimulated by the sentiments expressed in the Wisconsin legislature, or may have been a gesture by the astute Delegate to Congress from Wisconsin Territory, George W. Jones. Be that as it may, in the very next session of Congress following that which had created the Territory of Wisconsin the previous July, on December 19, 1836, Senator Lewis F'. Linn of Missouri and George W. Jones introduced identical resolutions in the Senate and the House asking that the Committee on Judiciary in the one and the Committee on Territories in the other be instructed to enquire into the "expediency" of establishing a separate territory of Iowa. That is as far as the movement got in the 24th Congress. for after being accepted by both houses, the resolutions were effectually buried in committee for the remainder of the session. Naturally Congress needed to be envinced of the need for a new territory when the area now petitioning for a separate government had been included in a territory established just six months before!

Before Congress assembled for its next regular session in December, 1837, several events had taken place in the two parts of Wisconsin Territory that stimulated a renewed effort to gain congressional action in creating a territory of Iowa. The first of these actions was taken on the western side, in the Iowa District itself. A special meeting of residents in Des Moines County, to be held at Burlington, was called for Sep-

\footnotetext{
${ }^{a}$ Congressional Globe, 24th Session, V, 30, 33.
} 
tcmber 16,1837 , to consider the special problems of that district. The first resolution offered at this meeting is the one that interests us at this time, for while there were resolutions that complained of the persistent delays in the mail service and the general inadequacy of that service for the growing needs of the country, and while others supported the land rights of the settlers and urged the quick settlement of the Missouri boundary line dispute, the first resolution resolved:

That while wo have the utmost confidence in the ability, integrity, and patriotism of these who eontrol the destinies of our present Territorial Government, and of our delegate in the Congress of the United States, we do nevertheless look to a division of the Territory, and the organization of a separate Territorial Government by Congress, west of the Mississippi river, as the only means of immediately and fully securing to the citizens thereot, the benefits and immunities of a government of laws.

Having met pursuant to publie notice, the County meeting adjourned with a motion that a meeting of represcntatives of the cutire western portion of Wisconsin Territory be held in the same city on November 6, to take collective counsel upon matter's relating to the whole of Iowa District. All the eight counties west of the river were invited to send three delegates each, Dubuque County, not having been sub-divided yet, and representing almost half of the area of the District, was to be permitted to send six delegates."

Just who initiated the first Des Moines County meeting at Burlington can not be satisfactorily determined, but it is probable that men with the vision and the interests of James Clarke, the young and successful editor of the Burlington T'erritorial Gazette, were largely responsible. Of the complicated skein of: interests that may have had a part in the calling of such a meeting, the case of James Clarke is illustrative-of the advantages to be derived from the location of the capitol and the "reasons" that helped to promote the movement for a new territory of Iowa. Having first established his newspaper, the Belmont Territorial Gazette, at Belmont, Wisconsin, where the first session of the Wisconsin legislature sat, Clarke followed the capitol westward to Burlington when the capitol was located there in 1837 and established the Burlington Territorial

\footnotetext{
Tlozva Nerus, September 30, 1837.
} 
Gazette. If the territory was not soon to be divided, and if Clarke would remain at the seat of government and receive his share of the legislative printing, he was faced with the prospect of transporting his newspaper and presses to Madison and commencing anew a third time. It may be that Clarke. had this in mind when he wrote to George W. Jones early in August inquiring of the likelihood of any congressional action on the Iowa territorial proposal in the coming session.

The news of the first Des Moines County meeting and the subjects proposed for Territorial Convention in November did not everywhere enjoy a cordial reception. Probably an evidence of the lingering scars of the battle for the territorial capitol in the legislature at Belmont, the Iowa News took firm exception to the first resolution drafted at the September 16th meeting: ${ }^{s}$

The importance which they [Des Moines County] attach to the question! of the division of the Territory, will prompt the citizens of Des Moines to use all the means within their power for the accomplishment of that object, and as there are serious doubts among our citizens as to the expediency of that measure, an early meeting for the expression of their views, [Dubuque County's], would seen to be demanded; that so far is the views of the people of this county accord with theirs, they may aid in the accomplishment of the objects, to which their attention is called, and to prevent the adoption of any measure not clearly established for the public good.

By this threat to the "public good" the editors clearly had in mind the division of the territory, as is apparent in the next paragraph of the editorial:

The several other subjects mentioned in their proceedings, and by which they call on the people of this county for their co-operation in order to succeed, should not be negleeted. We would suggest to our citizens the propriety of consulting each other, and appointing a day for a county meeting, and giving a general expression of their views.

The cool reception accorded the proposition to establish a new territorial government for the western district may have been due in part to Dubuque's pride and ambition which still hoped for territorial honors, and a suspicion that these hopes might be lost in the success of the present effort. And it may

sIbid. 
be that she may have had valid grounds for this hostile criticism. The original meeting at Burlington, and the proposal for a Territorial Convention in November, had come from that section of the Iowa district which had won the capitol location fight, which therefore already had that distinct advantage, and consequently could not be expected to place that in jeopardy in any proposal originating from them. Furthermore, added grounds for apprehension in a reading of the resolutions of the September meeting might have been found in the fifth resolution adopted by that assembly. By this resolution Dubuque County was allowed to send six delegates to the November meeting, double that of any other county; but even so Dubuque would be at a serious voting disadvantage in any contest with the southern portion of the territory with whom they had been at such bitter odds a scant nine months before. For these reasons or others, the Iowa News continued its opposition to the creation of a separate territory for the Towa District in its columns for October 7 . In calling the attention of: its readers to a notice of a "public meeting of the Citizens of: this county, on the 13 th inst," it gave as its opinion that "perhaps a majority of the citizens of this section of the county are opposed to a separation of Iowa from that part of Wisconsin on the Fast side of the Mississippi considering the measure premature and uncalled for at the present time." The paper's opposition was not an intransigent one, however, for it could write, "We would recommend an expression of public sentiment on this subject, and hope that the county of Tubuque will be well represented at the proposed Convention whatever may be its results."

This was the last public utterance of the Iowa News in oppostion to this one of the major subjects to be considered by the November Convention. Perhaps this abatement was in part due to the information contained in a letter addressed to the editors by W. W. Chapman, printed in the columns of October 14; Chapman was the United States District Attorney for Wisconsin Territory and had been a member of the Burlington meeting; on September 16 . In his letter, referring to the matter of representation of the various counties at the November Convention, Chapman states that the fifth resolu- 
tion of the September meeting as published was adopted by mistake through an error, unintentional but irredecmable. He asserted that he had offered to the drafting committee a substitute resolution for the one printed, which was adopted, providing that since it was generally believed the original Jubuque County would be divided into several smaller counties at the coming legislature, and since everyone knew approximately what those divisions would be, that the present Dubuque County be allowed as many representatives as if it had already been divided into these counties. This would estab. lish Dubuque on a parity of representation with the southern half of Iowa District, which had already been divided. But, Chapman wrote, through some inadvertent mistake, the original resolution, and not the one agreed to in the committee, was presented to the final meeting. Confident that his resolution would have been adopted if presented, Chapman urged Dubuque County to proceed as if the Des Moines County meeting had so acteci. His advice was apparently accepted by the residents of Dubuque, for at the town meeting held there on October 13, ten representatives were appointed, and another resolution was adopted that the balance of the twenty. one delegates decided upon be selected by other communities in the old county at special meetings, (indicating that seven countios were expected to be carved out of the old one). The other communities, however, apparently failed to act, for on November 6, Dubuque County was represented at Burlington by but ten men.

Of the eight counties then organized west of the Mississippi River, seven were represented by delegates at the November Convention, elected or appointed at various meetings held in the respective counties according to the suggestion of the first Des Moines County meeting. Des Moines County held her pre-convention meeting on Thursday, October 12." The town of Dubuque held their meeting on the following day, October 13 , at which it was

Resolved, That in the opinion of this mecting, the importance. of our Territory on the score of population, commercial enter-

\footnotetext{
Towa Journal of History and Politics, IX, 385.407. This gives the proceedings of the various county and territorial meetings that grew out of the meeting at Burlington, September 16, as found in the territorial papers of that period.
} 
prise, and of immense agricultural and mineral resources, demand that we should be organized at once as a separate Territory.

Louisa County likewise endorsed the demand for a separate territory for the Iowa District at a public meeting held at Wapello on Saturday, October 21. Among numerous resolutions touching upon all phases of pioneer settlers' interests, it was

Resolved, That we deem it highly essential to the interest and convenience of our Territory that a division of the same take place, and that in our opinion, the Mississippi suggests a very natural and proper line of separation.

A public meeting of the citizens of Henry County held at Mount Pleasant on October 23 also endorsed the proceedings of the Burlington meeting of September 16. And presumably the three other counties held similar meetings at which the aggenda of the November convention was accepted and approved.

The Convention duly assembled on November 6, with all eight counties but Cook represented. A three day session was held at which three vigorous memorials were drafted and prepared for presentation to Congress on the subjects of precmption land grants to settlers, settlement of the Missouri boundary line dispute, and a division of Wisconsin Territory. In the able memorial prepared by David Rorer, the memorialists complained that "perhaps no Territory of the United States has been so much neglected by the parent government, so illy protected in the political and individual rights of her citizens" as had the western (Iowa) district of Wisconsin Territory. Pointing out the need for an enlarged judiciary, for military protection for the "immense extent of country included within the present boundaries of the Territory," for more and better supervision of local administration, the petitioners did not fail to call the attention of Congress to the daily increase in population due to the long line of emigrant trains that poured into the Iowa District, and to the meagre populations that had sufficed for other territories to receive a separate territorial government. This petition together with the other was forwarded to Congress and was presented to that body by Delegate Jones on December 14, 1837. 
Whether Chapman's explanation had removed their objections, or whether it was deemed politic to be silent in their opposition since the town meeting had endorsed the proposed division of the territory, or whether it reflected the absorption of the settlers of pioneer Iowa in the subject, in their notice of the Territorial Convention in the issue of November 30, the editors of the Iowa News devoted the whole of their comment to the importance of the memorial relating to land grants and pre-emption rights of settlers, urging upon the readers the advisability of forwarding petitions to Congress upon that subject . . but not a word about a division of the territory.

On October 19, three weeks prior to the scheduled territorial convention at Burlington, a meeting was held at Milwaukee by the residents of that town to petition Congress for river and harbor improvements. One of the leaders of that meeting, Hans Crocker, writing to Jones the same day as the meeting was to be held, and informing him of the meeting, said "We will also express our opinions in relation to the division of the Territory. Upon the latter subject there will be no difference of opinion." That this was a favorable opinion is indicated by his further words: "I look upon the division of the Territory next in importance to our being admitted as a state into the Union. As such a measure will seatter a few crumbs among the office seekers at Washington, I do not think much opposition will be made to it on account of the impoverished state of the treasury." "10

Another significant action urging the division of the Wisconsin Territory was the memorial resolution adopted by the territorial legislature of Wisconsin itself." Since the majority of delegates in both houses of the legislature were from "Wisconsin proper," added weight was given to the step they took. Obviously inspired by the Territorial Convention which had

\footnotetext{
${ }^{10}$ Letter of Hans Crocker to George W. Jones, Oct. 19, 1837, in the George W. Jones Correspondence in the Historical, Memorial and Art Dept. of Iowa.

11 Journal of the House of Representatives of the First Legislative Assembly of Wisconsin, 1836-38, pp. 44, 66, 115 ; Joumal of the Conincil of the First Legislative Assembly of Wisconsin, p. 38; Subsequent sessions following the first session were complicated by the fact that the original representation from the counties on both sides of the river was retained, even though new ones had been created since the first apportionment; increased population made it further in arrears of the actual situation.
} 
assembled at Burlington the same date the legislature convened, although not a member of that convention, David $R$. Chance of Des Moines County offered a resolution in the House of Representatives on November 14, asking that a select committee be appointed "to memorialize Congress on the subject of the division of the Territory of Wisconsin." Chance, McGregor of Des Moines County, Parkinson of Iowa County, Sheldon of Milwaukee County, and Childs of Brown County were appointed on the committee. On the 17 th of November, on behalf of the committee, Chance submitted the following draft of a memorial which was quickly adopted:

The memorial of the Legislative Assembly of the territory of Wisconsin, respectfully represents - That owing to the great extent of country embraced in the limits of Wisconsin territory, and that vast extent of territory being separated by a natural division, the Mississippi river, rendering the application of the same laws oppressive or unequal to one section or the other. The true policy of the two sections of the territory being as widely different as their location, and the impracticability of the officers of the general government to administer the laws, render it highly important in the opinion of your memorialists that that portion of the territory lying west of the Mississippi river, be formed into a separate territorial government.

The territory of Wisconsin now contains fifty thousand inhabitants, one half of which, at least, reside on the west side of the Mississippi river.

Without any intention of censuring the official conduct of the officers in whose hands the administration of our infant. territory has been intrusted, but having the fullest confidence in the patriotism, wisdom, and desire to render that service for which their talents and experience so eminently qualify them, your memorialists would respectfully represent, that the westem portion of Wisconsin, with the population of twenty-five thousand souls, reaps but a small portion of the benefits and advantages of the fostering care and pro. tection of the mother government.

Your memorialists would further represent, that the popu- 
lation of Wisconsin is increasing with a rapidity unparalleled in the history of the settlement of our country. That by a division of the territory and the formation of a separate territorial government west of the Mississippi river, your honourable body would greatly advance the political and individual interests of her citizens.

Deeply impressed with the correctness of these views, your meniorialists would respectfully call your attention to a few facts.

The territory of Indiana was formed into a territory in the year 1800, with a population of only five or six thousand. The territory of Illinois in 1809 , with a population of about ten thousand. T'he territory of Michigan in 1805, with. a population of only about two or three thousand. The territory of Arkansas had a population of about fourteen thousand when she was formed into a separate territory. That portion of Wisconsin Territory lying west of the Mississippi, and which your memorialists pray may be formed into a separate territorial government, contains nearly double the population of Arkansas, nearjy three times the population of Inlinois, five times the population of Indiana, and more than ten times the population of Michigan, when they were formed into separate territorial governments.

Your memorialists repose entire confidence in the wisdom and patriotism of the Congress of the United States. Therefore your memorialists pray your honourable body to organize that portion of Wisconsin, lying west of the Mississippi into a separate Territorial Government.

On the $23 \mathrm{rd}$ of November the resolution was received by the Council and promptly passed. Governor Dodge affixed his signature to the memorial on the 29th of the month; it was then forwarded to George W. Jones at Washington, and likewise was presented by him. on the 14th of December.

In still another quarter was support for a new territory of Iowa found. Bushnell B. Cary, an editor of Racine, Wisconsin, wrote to Jones on the 29th of November, "We are circulating petitions for a division of the Territory and all sign and I believe we had best make an effort to become a 
state as soon as possible...." It will be well to note that both Milwaukee and Racine were on Lake Michigan, and were primarily interested in harbor improvements and establishing themselves as market depots for shipments to and from the east. There were undoubtedly other meetings in addition to these noticed here that favored a new territory for the "Western district of Wisconsin." 12

When Congress began its 25th session on the fourth of December, a considerable ground swell of articulate sentiment for an Iowa Territory had developed in consequence to the actions taken in the western territory. Congress, however, quickly became embroiled in the controversial heritages of Jacksonian rule, the same which had engaged its attention in the previous session: financial and tiseal problems and land questions were still far from a satisfactory solution. It was in this melee of argument that the supporters of the Iowa Territory project sought a second time to get congressional action on their proposal.

On the 14th of December Delegate Jones offered a host of petitions from his constituents, among which were the memorials from the Territorial Convention at Burlington on November 6, and the Wisconsin territorial legislature, dated November 29. On the same day Jones also asked that certain resolutions and petitions filed with the committees in the previous Congress be carried over into the files of the current session. Whether by this means Jones renewed his resolution of a year previous, asking for an enquiry into the expediency of establishing a new territory of Iowa, or whether he offered a separate resolution from the floor is uncertain. ${ }^{13}$ However it was, on the 14th of Deccmber such a resolution was filed with the Committee on Territories in the House, the same committec which had served as a morgue to their hopes the previous year. Although there is no indication that the same

\footnotetext{
${ }^{12}$ Letter to George W. Jones, Jones Correspondence.

${ }^{13}$ See the Congressional Globe for December 14, 1837, pp. 25-29. The Clerk of the House of Representatives, South Trimble, writes under Waslington date of June 29, 1938: ". . a careful search of the House Journal, which is the official record of the proceedings of the House of Representatives, fails to reveal any action on a motion or resolution of the Fourteenth of December, 1837, relative to an inquiry into the expediency of establishing a separate Territorial Government for Iowa."
} 
resolution was offered or renewed in the Senate, the probabilities are that it was.

Back in the territory, after the activities centering around the Territorial Convention had subsided, both the press and the settlers were strangely silent as to the necessity, or their hopes, for a new and separate government for the Iowa District. Perhaps they despaired of securing the attention of Congress or of gaining a favorable action. On February 17, the Burlington Gazette in commenting upon another meeting of the harbor improvement enthusiasts at Milwaukee in January, at which a division of Wisconsin Territory was again urged, pessimistically observed: "The division of the territory is a consummation devoutly to be wished for, but we fear, from present indications, that there is little hope of it soon ... Everybody on both sides seems to be in favor of it. There are a thousand arguments in its favor, and not a sound one, considering the whole ground, against it...." But even comments such as these were rare. A reading of the newspapers of that period indicates that the major interest of the settlers of the Iowa District was in the fate of the various land disposal schemes before Congress, and that on the whole they were indifferent to an "imperative" need of a separate government.

What a surprise it must have given those western settlers to learn that on the 6th of February, 1838, Isaac Bronson of New York, Chairman of the Committee on Territories, had filed the committee's report on the resolution of December 14, recommending a bill, H. R. 527, for the establishment of the Territory of Iowa. The report was not made without a struggle, as it had been stoutly opposed in the nine-member committee by "four opposition members," three Whigs and a North Carolina Democrat." In view of this stiff. committee fight, the unreserved recommendation of the proposal for a Territory of Iowa is noteworthy as reflecting the general strength of the measure in the House. The complete report of the committee is as follows: ${ }^{15}$

\footnotetext{
${ }^{14}$ Letter of Nathaniel Jones to Charles Mason, dated Washington, March 4, 1838, in the Mason Collection.

${ }_{15}$ Congressional Glabe, VI, 161; Reports of Comnittees, 25th Session, 2nd Ses. sion, Vol. II, Report No. 535.
} 
The Committeo on the Territories, who, by resolution of the 14th of December last, were instrueted "to inquire into the expediency of establishing a separate Territorial Government for that section of the present Territory of Wisconsin which lies west of the Mississippi river and north of the State of Missouri," and to whom were referred sundry memorials and petitions on that subject, respectfully report:

'That they have had the said subject under consideration; and that, from the memorials of the Legislative Assembly and the Territorial convention, and from the petitions of sundry citizens as well as from the representations of the delegate from that Territory, and others from other sources, they have become satisfied that the present Territory of Wisconsin is altogether too large and unwieldy for the perfect and prompt administration of the civil government thereof: that there are now about 50,000 inhabitants in that Territory, and that somewhat more than half of them reside on the west side of the Mississippi river; that the population of said Ter. ritory, and particularly on the west side of the river, is very rapidly increasing, more rapidly perhaps than any other part of the valley of the Mississippi and that, for the rapid development of the resources of the country, as well as to afford all reasonable advantages of a civil government and prompt administration of the laws to those persons living on the west of the Mississippi rivor, it seems to your committee that a separate Territorial Govermment should be established, to comprise that part of Wisconsin now lying west of the river. Your committee are satisfied that the judges of the Territory, as it now is, and also the Governor, district attorney, and marshal, are entirely unable to perform their respective duties in all parts of the Territory; and that the administration of justice, both civil and criminal, is seriously retarded, and, in many instances, rendered impracticable, from the causes above mentioned. The country is settled in detached portions, or squads, with large intervening tracts of uncultivated and unsettled lands; that, consequently, the means of. communication are not easy or frequent that many of the settlements are very far removed from the present seat of Government, and are entirely unable to hold frequent and direct communication with that place, which, for the present, is fixed at Bur- 
lington, on the Mississippi, but by law of last session, is to be removed to the vicinity of the Four Lakes, near the centre of eastern Wisconsin, as soon as the public buildings, now in a course of crection at that place, are completed. And when that erent does take place, your committee imagine that the necessity of a separate 'Territorial Government west of the river will be much increased, and that the just elaims of the citizens of that region of country to the protection of the Government, the advantages of eivil government, and the prompt administration of the laws, cannot be satisfied in any other way than by the ereation of a separate Territorial Government. Your committee have not, in the consideration of this subject, been unmindful of the fact that, by the ordinance of July 13, 1787, so much of the present Territory of Wisconsin as lies east of the Mississippi river must necessarily form one State, whenever the population of that portion of it is sufficient to entitle the inhabitants thereof to a separate State Government, (which time they believe is not far distant,) and that in adopting the Mississippi as a boundary between the two Territories they adopt not only a neutral boundary, but one which must necessarily exist by the ordinance aforesaid, between any future State to be formed out of said Territory and the remainder thereof.

F'or these reasons, as well as others which might be given, your committee have come to the conclusion that it is expedient to establish a separate Territorial Government over so much of the present Territory of Wisconsin as lies west of the Missisippi river, and for that purpose they beg leave to introduce a bill.

Such friendly action by the Committee was indeed notable progress over the fate the resolution had met in the previous session. The problem was now to bring the measure to the floor of the House and to secure favorable action upon the bill itself. Prospects for this were at first encouraging.

Then came the ugly incident of the 24th of February. Jonathan Cilley, a member of Congress from Maine, was killed in a duel with John Graves of Kentucky, also a member of the House. In this affair George W. Jones had the misfortune to act as a second to Cilley. Although duels were not 
uncommon, the official positions held by the two principles and the unusual circumstances surrounding this affair of honor shocked the nation. A violent storm of abuse was directed at the participants in this duel by the press and the citizens of the country, particularly of the North. The volume of the petitions that shortly deluged Congress made those that had been presented on the slavery question and on the annexation of Texas seem scattered and few in comparison; for their day, the number of the petitions compared with the avalanche of communications that buried Congress when the World Court proposal was being considered in 1935, or the reorganization measure of recent memory. In the Senate a bill was introduced to make death the penalty for all those apprehended as engaging in a duel in the District of Columbia . . another was more mereiful and asked but a long jail sentence, ${ }^{10}$ as the worried northern legislators tried to pacify the wrath of the indignant citizens, who, with some justice, considered Cilley's death plainly murder when they learned that after the first fire had passed harmlessly, a second had been exchanged with equally bloodless results, and that following this a third ball had been demanded, at which the member from Maine fell mortally wounded.

This tum of events which brought a special investigation by the House, and a daily flood of hostile petitions upon both bodies, presented Jones with a dangerous threat to both his political ambitions and to his Towa territorial bill. Aithough in an embarrassing position, and concerned over the effect of the duel upon his career, Jones did not despond, he had been in several ducls before, and his natural bouyancy of nature did not permit him to brood for long. Moreover, the western districts tended to minimize his share in the duel and to fix their surprised attention upon the news of Bronson's report. Jones hoped, therefore, to recoup whatever loss he may have sustained with his westem constituents by securing the passage of the Iowa territory bill, and perhaps becoming their first governor. The whole territory had immediately taken heart upon the news of the committee report on February 6 ;

${ }^{1 B}$ Congressional Globc, VT, 292 ff; Albany Jeffersonian, April 7, 1838. 
an air of expectant optimism is noticable throughout all the press of that period, in so far as opinions were expressed.

But it is a strange wind that blows no ill, the attendent publicity focused on Iowa and Wisconsin as a result of Bronson's report and the accounts of other travellers who had visited the western district did not meet with the full approval of certain other states in the west, who stood to lose by the westward movement of the emigrants which left them behind, thus lowering their land values among other things. As early as March, 1838, both the Iowa News and the Burlington Gazette comment upon the surly ill nature of the remarks reflecting upon the Iowa District which had appeared in the presses on the eastern shores of the Mississippi, especially in Illinois. The Burlington Gazette on March 24, took notice of these comments when it wrote:

Cry Down Wisconsin-represent it as a den of thieves and robbers, and then it is probable that some credulous emigrant some "timid fawn" may take the alarm and settle himself in some one of the 1000 and 1 houseless eities upon the opposite side of the river,-and this is the real and true cause of the hypocritical lamentations for our deplorable condition-our lawless condition-our savage condition.

Apparently the barbs of the Illinois brethren of the quill hurt, for the Burlington Gazette in the same issue complained at greater length of this disparaging treatment of the Iowa District :

In the attacks upon the eharacter of Wisconsin, recently becoming so very common, there is more meant than meets the eye. There is a spirit of jealousy and envy at the bottom of it -having its foundation in the superior advantages which the Territory holds out to the immigrant over that of some other sections of country not a 000 miles off; and its extraordinary advancement in all the elements of real greatness. This illiberal spirit and feeling is still partial, but there are efforts making by the speculating owners and proprietors of mushroom and paper cities and towns on both sides of the river, and especially on the sucker side, to make it general, and for that purpose the aid of the Press has been called in. If a rogue escapes from their own soils and pollutes ours with the commission of a crime, or if the most trifling fracas occurs in our widely extended territory, no matter how cansed or provoked, or what the eireumstance, the affair with all the deceitful trappings 
of mock morality, and pretended regard for public order, law, morality, \&c. is heralded forth in the most plaintive "laments," for our sad condition. We are then represented, not, indeed, in words, but by "lamentable hints and abominable innuenloes" as being without the pale of eivilization-without any of the restraints of civil society. ... Patriots and philanthropists, (for such ye doubtless are,) attend to your own business, and never mind ours. It will well become ye so to do. If ye liave any tears to shed reserve them for home consumption. Talk not to us about mobs, and riots, and murders, until at least the groans of your victims have died upon your ears.

Rev. Flijah Lovejoy was killed by an anti-abolitionist mob at Alton, Illinois, November 7, 1837. (See Iowa News for comment, November 15, 1837).

In the meantime the cause of the territory of Iowa was being advanced in Congress in the Senate. On March 14, Thomas Morris of Ohio, Chairman of the Senate Judiciary Committee, introduced "S. 269," a bill to ereate a separate 'Territory of Iowa, identical to $H$. R. 527 , which was referred to the judiciary committee (there was no Committee on Territories in the Senate). Working at surprising speed, the committee reported the bill back to the Senate on March 20 with but one amendment, which altered the length of tenure of the judges on the proposed territorial supreme court. This action in the Senate may have been but the natural result of an enlightened appreciation of the need for a new territory beyond the Mississippi felt by Morris and his committee, but one suspects the presence of the fine hand of a skilled parliamentary strategist in the timing and the quick committee action. With the House bogged down in debates over John Quincy Adams' dogged persistence in presenting anti-slavery petitions and with the threat of a highly controversial report from the duel committce hanging over the House, the initiative in the Iowa bill appeared to be forced on the Senate-if the measure was to be acted upon that session. A favorable action in the Senate would tend to force a consideration of the bill in the House, which was all that was deemed necessary for its successful passage."

This senatorial action injected new optimism in the Iowa

${ }^{17}$ Congressional Globe, VI, 239, 247. 
District's expectations of a new territory. A letter from Washington appeared in the Burlington Gazette on the 31st of March, stating that "there is a very good prospect of having Wisconsin divided. I have been talking to many of the members on the subject, and have not yet heard the first objection to it. The "Wisconsin Senator," as he is here termed, Dr. Linn [Senator from Missouri], is using every exertion to have it carried through and thinks there is no doubt of its passage ... so does our Delegate. . . " Another letter published in the Towa Patriot, dated from Washington, March 29, 1838, stated that "the division of Wisconsin and the organization of the Territory of. Lowa is now considered certain . . Public attention begins to be drawn to your section of the country."

Despite the seemingly favorable signs seen by the Washington observers, the Iowa Patriot on April 1, interposes an uneasy if when it notes that it had been taken in by the exaggerated rumor, based on the report of the Senate committee, that the Iowa bill had become a law, and comments that "if ... Congress has any regard to the public sentiment existing on both sides of the Mississippi in reference to this subject, we confidently anticipate that the division will take place during the present session."

The suggestion that personal ambitions and local pride and private profit secking had considerable to do with the agitation for a new territory of Iowa receives partial support in the cool editorial comment of the Iove News on April 14, 1838, when it calmly writes: "Although remaining a component part of Wisconsin Territory does not necessarily impose upon us any great evil, yet as the two districts must necessarily be divided, and our population is sufficiently strong to justify the division, the sooner it is made the better." That in brief was the whole argument for a new Iowa Territory in 1838. Although irritations and annoyances may have been felt in the Iowa District from being yoked to Wisconsin Territory, there was no wide spread resentment among the residents on one side towards those on the other side of the river. Some papers tried to suggest the presence of a deep seated animosity, but this was largely the fiction of eastern papers, or of writers whe had a personal motive inspiring a 
prejudiced pen. In fact, some of the articles appearing in the eastern papers, the Washington Globe, ${ }^{19}$ for instance, if not a garbled misunderstanding of the bitter ill feelings created in the capitol fight in 1836, may have been "inspired" to stimulate attention to the pressing need of a new territory west of the Mississippi and to the bill pending in Congress. While it is true that Dubuque did not soon forget the lack of support rendered her by the southern delegation in the first Wisconsin legislature, the Iowa News and the other territorial papers were free from attacks upon the eastern portion of the territory, except where the personal feuds of the editors found room for personalities in attacks upon their fellow craftsmen.

With the Towa measure marking time in Congress following the Senate report on March 20, the certainty of a division of the immense Territory of Wisconsin continued to grow in the Iowa District. This optimism is reflected in the increased political activity that developed. A resolution endorsing George W. Jones as governor of the new Iowa Territory was signed by 59 residents of Davenport in March, 1838. On April 20, a mass meeting at Dubuque nominated Jones to the same position and likewise forwarded their memorjal to President Van Buren. The line of political advantage and the technique of gaining favorable publicity to such eandidacies is revealed in the letter John Plumbe Jr., secretary of the Dubuque meeting, wrote to Jones, counselling that the memorial be inserted in the Washington Globe and in other papers in the national capitol. Prospects of a division of the territory appeared so favorable that on May 9, the Iowa Patriot, edited by the redoubtable James G. Edwards, urged the immediate likelihood of an Iowa 'Territory as one of the reasons why the sheriffs should speed their census count in the Iowa District in preparation for the special reapportionment session of the territorial legislature which was to meet in June. The arguments for a new territory could well be buttressed by the latest count of the population, which was confidently expected to be large. ${ }^{10}$ 


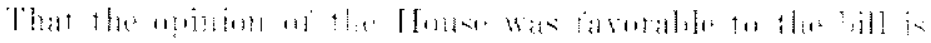

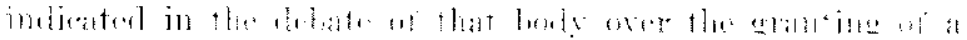

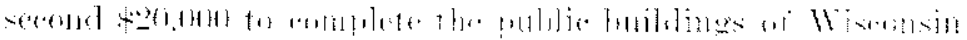

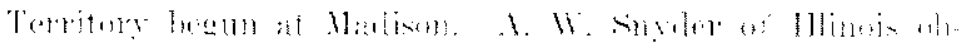

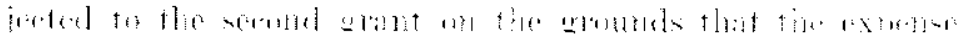

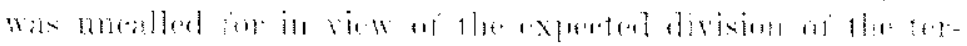

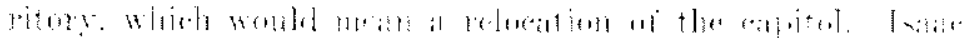

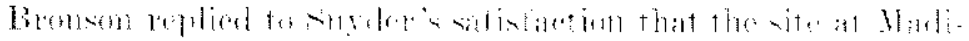

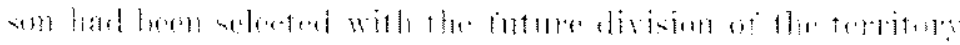

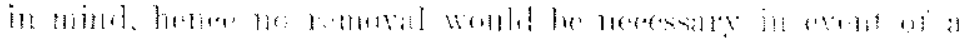
Tixisiont.

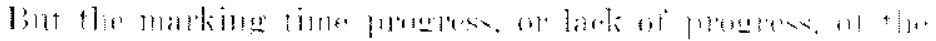

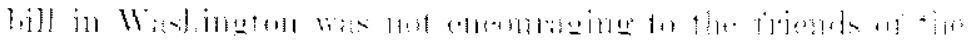

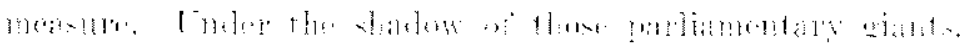

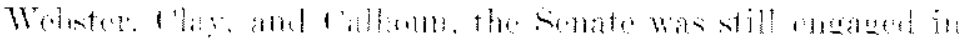

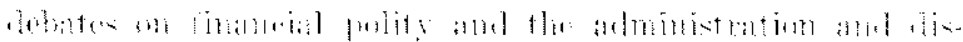

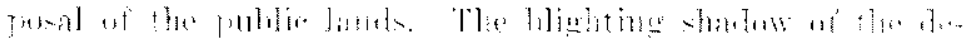

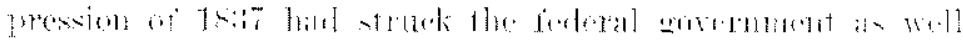

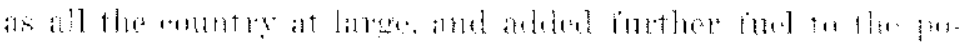

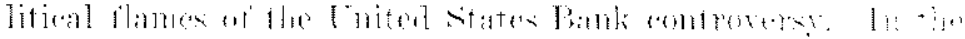

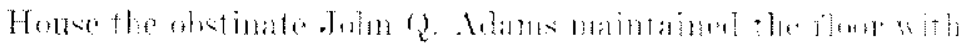

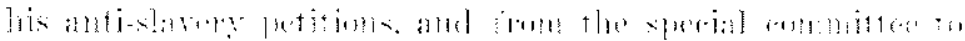

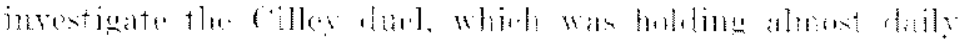

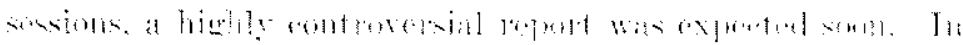

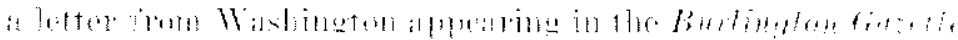

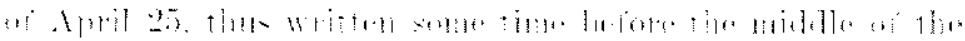

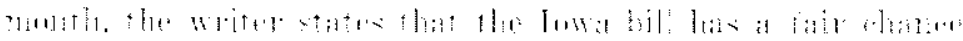

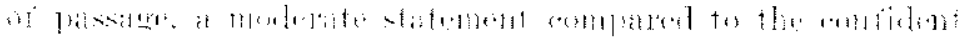

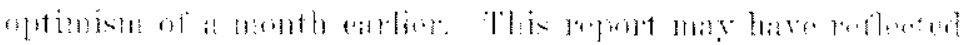

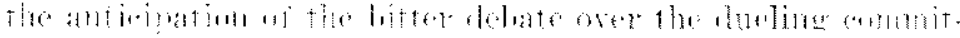

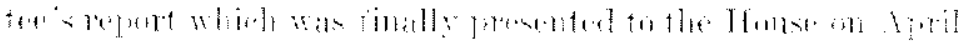
21.

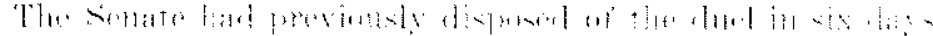

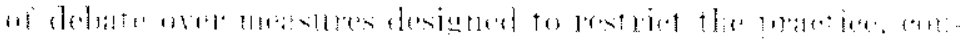

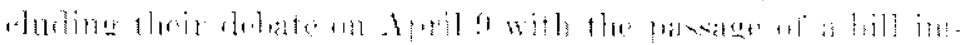

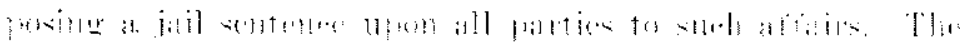

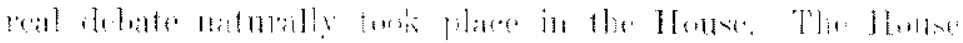

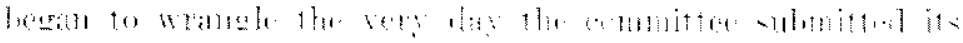




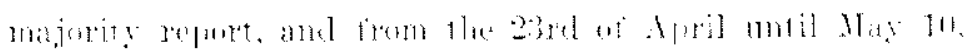

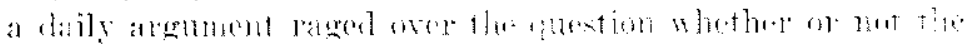

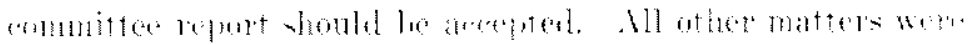

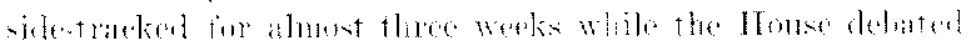

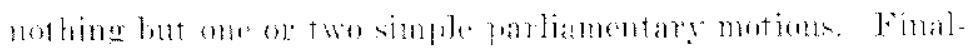

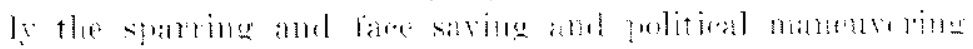

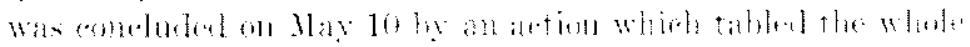

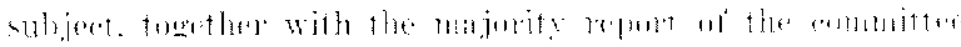

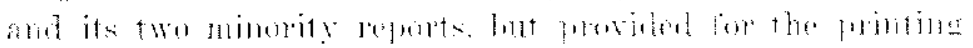

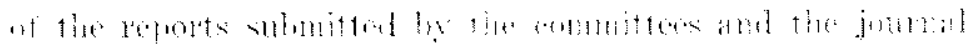

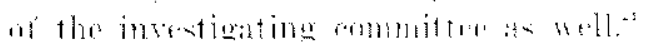

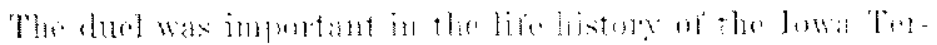

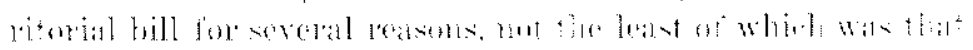

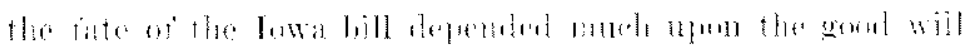

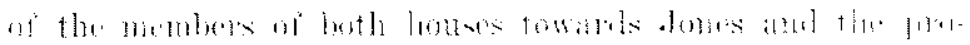

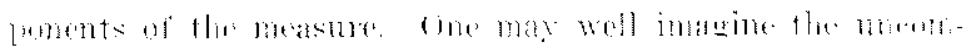

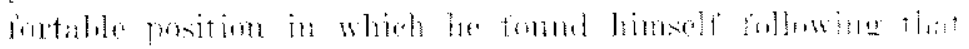

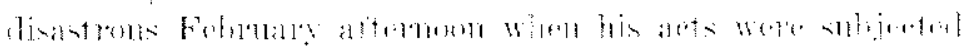

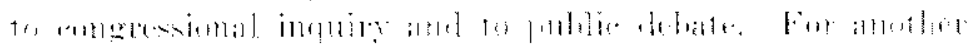

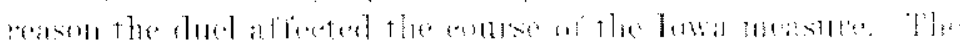

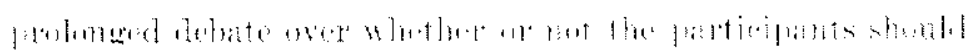

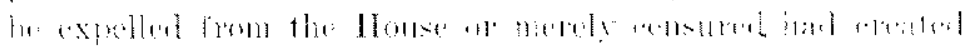

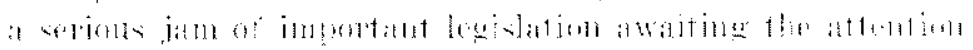

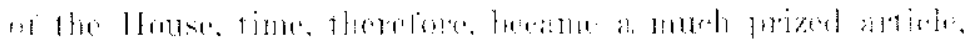

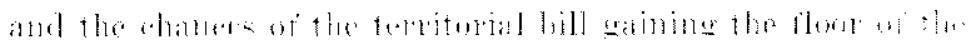

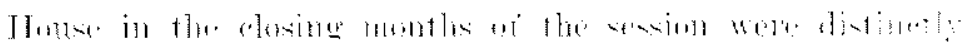

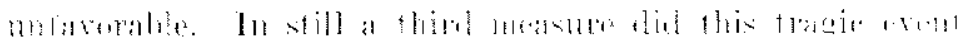

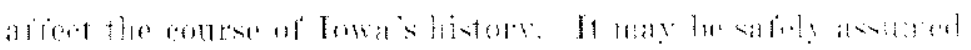

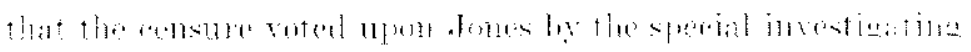

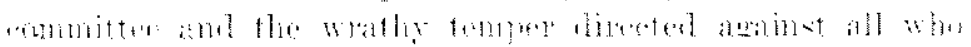

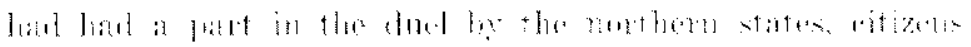

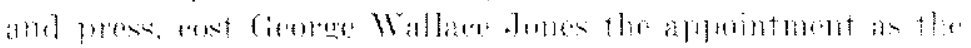

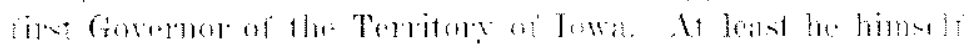

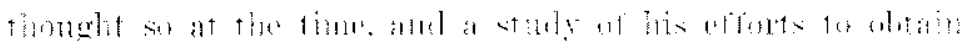

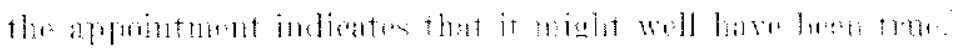

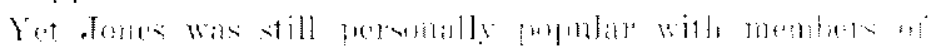

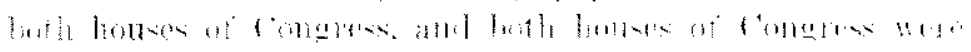

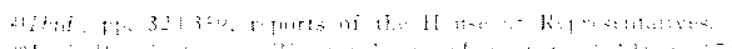

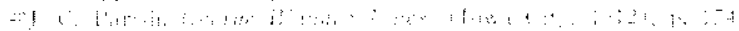


favorably disposed towards the establishment of an Towa Territory. Success depended, therefore, upon gaining the time of: Congress for a consideration of the measure. On May 11, 1838 , Isaac Bronson moved that the 22nd and the 23rd days of May be set aside for a consideration of bills relating to territories. Cambreleng, Chairman of the Finance Committee, expressed reluctance to have the calendar of the House tied up in advance when it was uncertain how much time the pressing public measures would require in debate. Bronson quickly accepted a proposal that the dates be shifted to the following week, the 29th and 30th of May, but the motion, significantly enough, was defeated even as amended. A week later, on May 17, even though the Chairman of the Committee on Territories had failed, George W. Jones attempted to force the House to set aside time for territorial bills by his own strength. His motion that the 5th and 6th of June be set aside was accepted by the House without a murmur. But this favor, one may be sure, would be quickly sacrificed if the pressure of business became too great. The best strategy again seemed to be to force the House to keep its word. Thus with Cambreleng impatient to begin the discussion of the public finance bills, good strategy dictated that the Senate take the first action if possible, this would be easier for that body to do, since it had not been so long delayed by side-issue debates as had the House, consequently it would be easier to find time on the calendar. ${ }^{23}$

On the first of June the Iowa bill was called up for consideration in the Senate. The debate was comparatively brief, the main arguments advanced for a creation of a new territory were those of the unwieldly administrative size of Wisconsin Territory and the increasing population of the western district. The only real debate centered around the committee amendment proposing to make the term of the judges four years instead of for life or good behavior. Webster, Grundy, Morris. and Sevier successfully supported the restriction on the grounds that the constitutional provision for life or good behavior in the appointment of federal judges applied only to the states, in a political and a geographical sense. Critten-

${ }^{23}$ Congressional Globe, VI, 362, 380. 
don of Tennessee succeded in having the terms of the legislators reduced in the Council (upper body of the legislature) from four to two years, and in the House from two to one. Neither of these amendments could have been objected to by residents of Wisconsin or of Iowa. This restriction of the judicial tenure may even have been at the suggestion of leaders on both sides of the Mississippi. They had before them the example of Judge Frazier of the Wisconsin Supreme Court, who with his other two colleagues held his position during "good behavior." Frazier was not only frequently drunk, but was bitterly disliked by the leading lawyers who practiced in the courts over which he presided, moreover, he was generally unpopular for his habit of scuttling off to his home in Pennsylvania as soon as his court sessions were over. On the second point, ambitious young attorneys welcomed the short term in the legislature because it gave more of them a better opportunity of making a start in their political careers. All told there was little opposition to "Senate 269," it went to its third reading without a struggle, and on the final passage of the bill, on the motion "Resolved. That the said bills pass, and that their respective titles be as aforesaid," no roll call vote was ordered, and the bill went to the House for the latter's concurrence therein. ${ }^{2+}$

The bill encountered stiffer opposition in the House. ${ }^{25}$ Senate 269 was reported back to the House without amendment by the Committee on Territories, to which it was referred, on June 5 . Since this was the date set aside for the consideration of territorial matters, Bronson moved that the House go into a Committee of the Whole for a consideration of the orders of the day, John Sergeant of Pennsylvania was in the Chair. (A committee of the whole is actually the whole membership of the legislative house sitting unofficially, whatever action it takes is as a committee and not as the official action of that particular body of the legislature. The "committee" later "rises" and sits in its official capacity, when it must then accept or reject the action it took as a committee. This is a useful method of proceeding with controversial matters

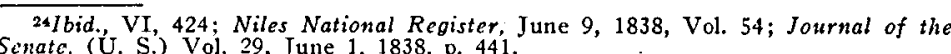
Senate, (Ü. S.) Vol. 29, June 1, 1838, p. 441. 
or with long detailed bills, like appropriation bills, for instance.) Of the nine bills to be taken up in the Committee of the Whole, the Iowa bill was numbered six. A frontal attack was immediately begun by Mason of Ohio, who, skeptical of establishing a government of law for a people who had "squatted" on public lands contrary to the law, moved to strike from the bill all after the "Be it enacted" clause. This amendment if accepted would, of course, have killed the bill. Though not as serious a one, another unfriendly gesture was made at this time, when a motion was offered to lay the whole bill over: since it was going to provoke long debate it would delay a consideration of the other territorial measures. If laid over the bill could be called up for consideration again at a later time, but it would lose its priority of position on the docket of the House. This motion was defeated. With Mason's motion still pending the real opposition to the measure was frankly unmasked by Waddy Thompson Jr. of South Carolina. He asserted that he would "never consent to the coming in of these Territories or States into the Union, when the fanatical spirit of the North, was pouring into the House memorials against the annexation of Texas, simply because it was cursed with the peculiar institution of the South." It was immediately pointed out to the representative from John Calhoun's state that the Northwest Ordinance imposed an obligation upon the federal government to create territories and, later, states when certain conditions had been fulfilled, and further, it was made clear that the proposed territory was now a part of the United States, whereas Texas definitely was not. Thompson clarified his opposition by saying that he wished to settle the admission of new states into the Union now, rather than waiting until 100,000 people in the territories knocked at the door of Congress for admission; the balance of power, he maintained, must be preserved between the North and the South. Such remarks, though out of order, were revealing. Mason's motion was then defeated without a division vote. The committee did accept, however, an amendment cutting the salary of the Superintendent of Indian Affairs (who was also the governor) from $\$ 1500$ to $\$ 1000$.

When the Committee of the Whole arose and the House sat 
again in its official capacity with the Speaker in the Chair, the report of the committee was accepted unanimously by the House on all bills considered by it in committee with the exception of "No. 6" - the Iowa bill. The committee amendment as reported was adopted, however, on a separate vote. The bill nevertheless, had not yet escaped the threat of a stillborn death, for the persistent and honest Waddy Thompson moved to lay the committee's report on the table, thus killing the bill, since a two thirds vote would be required to take it off the table. On the yeas and nays being taken this attack was beaten off and the House adjourned to resume consideration of territorial measures the following day, June 6 .

Echoing the distressed condition of the federal treasury and the country as a whole, the debate commenced on the sixth with a clash over the governor's salary (his salary as Superintendent of Indian Affairs had been cut $\$ 500$ the day before). Among others who deplored this parsimonious economy in paring the remuneration of a man who would govern a territory larger than the combined area of many of the states in the older east was John Q. Adams. But William Bond of Ohio, Mercer of Virginia, and Harlan of Kentucky found support among friends of the bill; in order to hasten the final consideration of the bill George W. Jones agreed to the amendment, and Isaac Bronson likewise acceded to the reduction of $\$ 500$. This amendment quickly adopted, the House immediately proceeded to reduce the salaries of the judges of the federal territorial courts by three hundred dollars, from $\$ 1800$ to $\$ 1500 .^{26}$ An interesting side light on the drafting of the Towa bill is seen in Bronson's statement in accepting the salary slash, when he said that the Committee on Territories "in drafting this bill, had been led into an error, by taking the House bill for Wisconsin as the model for this, forgetting that the salaries had afterwards been reduced in the Senate."

A fair test of strength on the bill was made when the indefatigable Thompson offered a motion to lay the whole bill on the table. The motion was lost, 42 to 134 . A last effort to postpone the establishment of Iowa Territory was Mercer's

20Tipton of Indiana maintained that a $\$ 1500$ salary was the average for most judges in the state courts. 
motion to amend by providing that the bill should become operative only when Wisconsin became a state. This too was beaten. The bill finally passed by a vote of 118 to 51 and was sent to the Senate for concurrence in the House amendments.

The arguments for the creation of Iowa Territory in the House followed the stereotyped ones of size, growth of population, and the comparative number of settlers in other districts at the time territorial status was conferred on them. One of the most interesting speeches made in the House debate, however, was that of Charles Shepard of North Carolina, speaking in opposition to the bill. ${ }^{2 \pi}$ Not mentioning slavery, he yet introduced other interesting differences between the North and the South. First complaining that it was not fair or honest to the rest of the nation to permit settlers on the national domain to select the choicest of lots for their own personal use by "squatters' rights" when the land was a form of national wealth belonging to all the citizens of the country, Sheppard prophesized that once a government for the whites was carried across the Mississippi River it would soon extend to the Rockies and the Oregon. This combination of a liberal land policy backed by governmental organization worked incalculable harm upon the nation, he maintained, for by providing an easy outlet to the west it removed a restraint upon the morals of society, it denied the country the benefits of competition a compact and densely settled area produced, stimulating inventions and industry. Significantly Shepard decried the fact that this liberal land policy worked to the disadvantage of the South in still another way, for by releasing the energy of the North to the west, the "surplus of Northern enterprise and energy which would have flowed to the South" was lost to that section. It was an interesting speech and far from a weak one, but Shepard was opposing "Manifest Destiny" and had to vield to the restless pressure of frontier democracy.

When the bill was reported back to the Senate on the same day the House took its final action, June 6, Preston of South Carolina made the last attempt to kill the measure by moving

${ }^{27}$ Congressional Globe, VI, Appendix, pp. 511-12. 
to liny the whole bill on the table. When a roll call vote showed but five other Senators voting with Preston in favor of the motion, the opposition collapsed, and the Senate quickly concurred in the House amendments and the bill was sent to the President for his signature. ${ }^{23}$

In closing this brief chart of the course of the Iowa bill from an Idea to a Reality, it may be well to note that, it was aided by other factors not already mentioned, which perhaps insignificant in themselves, in their collective weight were of no slight assistance. Since Wisconsin, by provision of the Northwest Ordinance, was sooner or later to be separated from the district west of the Mississippi, the technique of Jones, Linn, anc others appears to have been to forward the Iowa bill by initiating those steps which would lead Wisconsin towards statehood, even though her population was far below the statutory requirement of 60,000 , and though her territory was not yet clear of Indian title. By this means they may have hoped the inevitability of a separation of the two districts would be subtly impressed on Congress. Thus, on March 5 , the House accepted a motion offered by Jones asking that the Committee on Territories be instructed to inquire into the expediency of taking a census in Wisconsin and authorizing the drafting of a constitution as preliminaries to Wisconsin being admitted into the Union. The diligent and obliging Committce on Territories reported out a bill on May 11, au. thorizing the preliminary steps for the establishment of a state of Wisconsin. A petition from residents of Wisconsin Territory east of the Mississippi urging statehood for that area was received in Congress on the 21st of May. Though much talk had taken place in the territory upon the desirability of early becoming a state, this was the first petition received by the 25th Congress, and the last that session. It may have been only a coincidence that on the 17 th of May George W. Jones

28Ibid. VI, 435. According to the popularly received story told by George Wallace Jones in his reminiscences of later years, the Iowa bill was passed in the Senate due to his cleverness in getting Calhoun out of the Senate chamber when that measure was considered. This, if it had any actual basis, probably referred to the Senate session of June 6, when Preston made the last effort to kill the bill. The records of both that day and of June 1 st do not show Calhoun voting in any of the roll calls. Even if the absence of Calhoun from the Senate when the Iowa hill was being finally debated may be credited to Jones, the vote on Preston's motion indicates that Jones' claims were exaggerated as to the importance of his strategy. 
gained the consent of the House to set aside the 5th and 6th of June for a consideration of territorial matters. ${ }^{20}$

Likewise the need for military protection to the settlers in the west, and in the Black Hawk Purchase as well, was called to the attention of members of Congress by a resolution offered by Cushing of Massachusetts which asked the President of the United States for a report, "if in his judgment not incompatible with the public interest, of any intermeddling of any foreign government or subjects or officers thereof, with the Indian tribes in Michigan, Wisconsin, the Territory beyond the Rocky Mountains, or elsewhere," with the implication that military arms were being supplied to these tribes. Then too, there was the novel proposal of Crittendon of Tennessee to establish an "Indian Territory" called "Neosho," west of the states of Missouri and Arkansas and embracing all lands in which Indians still held title, giving to these red men. a territorial government and a delegate in Congress. Though this measure may have been prompted by the severe twinges of conscience produced by the conduct of the United States towards the Seminoles and Creeks of Florida and Georgia, it was debated at some length in the Senate and was warmly favored by Benton and Linn of Missouri. Whether this was a serious gesture need not be debated here, that it did serre a purpose in directing the attention of eastern Congressmen towards the unsettled state of the west and the need for new military posts, perhaps arsenals, or hospitals on the western waters, is plain, equally plain is it that the Towa bill benefited as much from this attention to the west as did these other interests. The Iowa News, however, did not share in this solicitous concern for the red man, and editorialized that the whites shouid be given first consideration, and granted a territorial government before any Indian. The importance attached to the presence of Indians on the frontier was not fictitious; one has only to refer to the fact that the governorship of the Territory of Iowa was first offered to two men, Brigadier General Thomas S. Jesup and Brigadier General Henry Atkinson, both army men and both experienced in Indian warfare, that the man who finally accepted the appointment likewise had be-

\footnotetext{
${ }^{20}$ Congressional Globe, VI, 208, 363, 394.
} 
hind him an impressive military record, and that even such a good friend of George Jones as was Senator Benton would indorse the former as the governor of the new territory only if it were not considered a military post. ${ }^{80}$

On Tuesday, June 12, President Martin Van Buren signed his name to the engrossed Iowa bill, making it a law. On the following Fourth of July Iowa Territory was to begin its first year of official existence ... the hundredth of which we are cclebrating this year.

Despite Amos Kendall's (Postmaster General) "Express Mails," news a hundred years ago travelled but slowly, and authentic news even more so. With the information that decisive action upon the Iowa bill was to be taken on the 5th and 6th of June, the Iowa District awaited anxiously the results of those two days of deliberation. Easily puffed rumors based upon a part of the congressional action in one or the other house made it difficult to distinguish fact from fietion, consequently for two or three weeks in June the Iowa press carried a vacilating story of hope, fear, and fact. One of the first to hear the actual news was Peter Hill Engle, who read the news in the Missouri Republican of June 20 ; he wasted no time and wrote to Jones that same day recommending a candidate to an appointive office. The Burlington Gazette on the 23rd of June was confidently hopeful when it wrote "This is a great crent, and great will be the consequence. In the twinkling of a' bedpost as Lord Duberly says, we shall have the population for a state-and a state of such a character for real growing greatness." One reminiscent pioneer later reeollected that the authenticated news of the signing of the Towa bill reached Burlington on the 25th of June, and that the Wisconsin legislators departed on an upstream steamer the same day. On the 27th of June the Iowa Patriot based its conviction that the longed for event had actually taken place upon the fact that at Burlington no great opposition had been made to the crating-up of the Wisconsin territorial library and its shipment to Madison, nor had any delay been interposed to the auctioning of the legislative furniture. Finally

\footnotetext{
${ }^{30}$ Albany Jeffersonian. March 31, 1838: Congressional Globe. VI, 388 ff.: Jones Correspondence, May 26, 1838; Mason Collection, letter of Lt. A. M. Lea, dated June 12,1838 .
} 
in the issue of June 30, the Burlington Gazette was able to print the entire organic law of the Territory of Iowa.

With confident faith in the future of the young territory, the settlers prepared for its first jubilee on the Fourth of July. With pride in the record of that past, Iowa looks forward with equal confidence and faith to the next hundred years that lie ahead.

\section{TERRITORIAI NOTES}

The Mississippi River.--A report from the U. S. engineering department,-states that the number of snags taken out of the mouths of this river during the year 1837, amounted to about 1894. The engineer deems the expense of closing all the mouths but one, or making a ship canal, too expensive. Every snag pulled up by the steamer employed costs now $\$ 13$, the price advancing as the snags diminish. The peculiar obstructions could be avoided, if the caving banks were cleared of all timber, of which there have been felled this year 18,141 trees. The wash of the serpentine current causes the caving of the banks.-The New Yorker, New York, N. Y., April 21, 1838.

Fast Travel.hing.-A gentleman of this place arrived yesterday morning on the Rolla having come up from New Orleans in ten days, less seven hours, including 27 hours spent in St. Louis. This is the quickest trip ever made on the Mississippi. He came on board the steamer St. Louis as far as St. Louis.-The Iowa News, Dubuque, Wisconsin Territory, June 9, 1838.

\section{NoTICF}

Owing to the scarcity of cash, the subscriber will receive the following articles, viz: Corn, Oats, White Beans, Wood, Flour, Butter, Eggs, and Iard, at cash prices in payment of fee for recording. Fces in all cases to be paid in advance.

$$
\text { Jno. D. Evans. }
$$

Recorder's Office, Feb. 21, $18422 \mathrm{w}$

An advertisement appearing in the Dubuque Iowa News, February 2S, 1842. 
Copyright of Annals of Iowa is the property of State of Iowa, by \& through the State Historical Society of Iowa and its content may not be copied or emailed to multiple sites or posted to a listserv without the copyright holder's express written permission. However, users may print, download, or email articles for individual use. 